\title{
STRUCTURAL VIOLENCE ENSUES IN MYANMAR: THE ON-GOING FEROCITY AGAINST ROHINGYA MUSLIMS
}

\author{
Shireen Mushtaq ${ }^{a}$, Sidra Masood ${ }^{a}$ and Tuba S. Kazmi ${ }^{a}$
}

\begin{abstract}
Rohingya Muslims have been subjected to structural violence committed by the Government of Myanmar and the military junta for several decades. The sheer refusal of rights of these people is a classic example of structural violence as explained by Johan Galtung's Theory of Structural Violence which stipulates that violence occurs in three forms: Direct, Cultural and Structural all of which have been committed against Rohingya Muslims. The combination of direct and cultural violence leads to the continuation of the structural violence as seen in the 1982 Citizenship Act that legitimizes and institutionalizes the violation of rights of Rohingya Muslims in Myanmar. The research is based on qualitative method and secondary data. The paper primarily focuses on the application of the Theory of Structural Violence in the case of Rohingya Muslims, and highlights the problems faced by the Rohingya due to this ostracism. It also aims to look at the standing of other states in the region pertaining to this issue.
\end{abstract}

Keywords: Rohingya Muslims, Structural Violence, Human Rights, Ethnic Cleansing, ASEAN

\section{INTRODUCTION}

The Rohingya Muslims of Myanmar - an ethnic minority, are considered a persecuted minority in the world. They are stripped of their citizenship, and their ethnic origin is denied by the Government of Myanmar. This minority group, making up to a 1.33 million population of the total Muslim population in Myanmar, has been confined within the Rakhine State. They are seen as victims of oppression and violence orchestrated by the Government of Myanmar and religious extremists. They have been culturally, socially, economically and politically discriminated based on their religious and ethnic beliefs and roots. Myanmar has stripped the Rohingya Muslims of these rights, and the latter's status as a minority group of their state is also not recognized. Though officially, the Government of Myanmar recognizes 135 minority groups, including other ethnic Muslims, this recognition is not extended to Rohingya Muslims (Dittmer, 2010). The Citizenship Act of 1982 has deprived Rohingya Muslims of their rights and effectively rendered them as stateless people.

The identity of Rohingya Muslims remains a debate in Myanmar. There are two conflicting theories regarding it -

(i) Rohingya Muslims are descendants of the illegal immigrants who travelled from Bangladesh to Myanmar (Saw, 2011; Ahmed, 2012); and

(ii) Rohingya Muslims are residents of the Arakan State since the reign of the Arakan

\footnotetext{
a Corresponding Author: Shireen Mustaq (shireen.mushtaq@kinnaird.edu.pk) and Co-Authors are Sidra Masood (sidramasood.95@gmail.com) and Tuba S. Kazmi (tubasyed786@gmail.com). Authors are affiliated with the Department of International Relations, Kinnaird College for Women, Lahore, Pakistan.
} 
Kingdom, and are descendants of the original Muslims who converted on Ramree Island (Bahar, 2010; Foster, 2011).

Despite these different and conflicting debates, it remains true that Muslims have been part of Arakan for hundreds of years (Mohajan, 2018), but due to cultural discrimination, economic exploitation, religious differences and political deprivation (Wolf, 2017), the Rohingya in Myanmar have become victims of persecution. They are denied all kinds of foreign aid and are kept in complete isolation and locked down from the outside world. A post positivist analysis of the situation based on the qualitative method describes the atrocities committed against Rohingya Muslims, and provides that the violence committed is in fact, under the typology explained by Johan Galtung, labeled as Structural Violence.

This paper is divided into four main sections. Section 1 will provide a historical overview of the conflict, Section 2 focuses on the theoretical framework, Section 3 will discuss the impact of the structural predicaments, and Section 4 will highlight the regional response. The conclusion is presented at the end.

\section{THE HISTORY OF THE ROHINGYA CONFLICT}

The Rohingya Muslims claim to be the descendants of Arab traders who arrived in Myanmar through Ramree Island in the 18th century (Ullah, 2011). They claim that the traders had asked for Rahm (which means mercy in Arabic) of the then ruling King, whereby they were then allotted a piece of land on royal command to settle and start their livelihood. With the passage of time, the term Rahm evolved and changed to Rohang, and eventually Rohingya (Chowdhury, 1996; Bahar, 2010).

\section{The Demography of Rakhine State}

The Rakhine State has been home to two distinct Muslim ethnicities, Kaman (Myanmar Muslims) and Rohingya Muslims. However, due to their physical appearance and cultural association, the former were provided citizenship, whereas the latter were termed illegal Bengalis, and eventually stateless people (Minority Rights Group International, MRGI, 2008). Kaman Muslims are not only similar to local Myanmar citizens in appearance, but they also share the same language and customs with the Buddhist population. However, the Rohingya Muslims, due to their territorial proximity with the Bengali Muslims, they speak the Chittagonian language (dialect) of Bangladesh, and have the same physical appearance as the Chittagonians. Hence, the Buddhists believe that Rohingya Muslims are in fact Bengali immigrants who came into Arakan in the $19^{\text {th }}$ century. This social difference has made Rohingya Muslims prisoners of the Rakhine State, whereby they cannot leave without governmental permission (Integrated Regional Information Networks, 2012).

\section{The Beginning of Tensions between the State and the People}

The contradictions between Rohingya Muslims and the Buddhist of Myanmar started when General Ne Win took control of the government in 1962 through a military junta. The conflict started to take shape when Rohingya Muslims were deprived of their basic citizen rights on the 
basis of professed fear of Islam (Crouch, 2016). The resulting turmoil of this attitude of the Government of General Ne Win had led to an action-reaction scenario in which Rohingya Muslims found no way, but to resort to other means to protect themselves from state aggression. In the 1970s, Rohingya Mujahedeen formed a Rohingya separatist movement, as was the case with most minority rights situations during the Cold War period. The movement launched several operations to take back control of Rakhine State from the Myanmar Government. Consequently, in retaliation, the Myanmar Government launched a massive military operation named Operation Nagamin (also known as Operation King Dragon) in Rakhine State in February 1978 which took the lives of hundreds of Rohingya people. The objective of the operation was to expel the so-called foreigners from Rakhine State prior to the national census.

Rohingya Muslims refused to identify themselves as "illegal Bengalis" in order to obtain Myanmar citizenship, whereas the Government refused to provide them with citizenship unless Rohingya Muslims left their "Islamic" heritage behind, or gave up their religious beliefs. This attitude of the Buddhist Government was driven from the fear that if Rohingya Muslims remain attached to their Islamic faith and identified as nationals of Myanmar, the state might lose its Buddhist identity (Chia, 2016).

According to evidences that highlight the antiquity of Rohingya origin, it should be acknowledged that Rohingya Muslims are very much part of Myanmar, even according to internationally accepted definitions of ethnicities, minorities or nationalities. They have long perennial ties to the land and have been around for a long period of time; they have a shared history and were born in a community that shares culture, values and leaders. Apart from being recognized for their ancestral claims and identity, it should be noted that Rohingya Muslims claim their right to be Myanmar citizens based on being a nation as per the primordial views. As Jacques Leider explains in his work, for in Myanmar, as compared to other countries, ethnic recognition is essential to acquire primordial constitutional legitimacy for not only political representation, but also "citizenship" (Pisharoty, 2017). Hence, it was important for "first" generation Rohingya to be recognized as citizens of Myanmar based on their primordial ethnicity - Rohingya Muslims. However, their claim of ethnic origin is largely contested due to their diverse historical background (Leider, 2013).

\section{Rohingya Muslim Minority}

The two major driving components of the Rohingya people are their "Rohingya" identity and their Islamic faith. Both have primordial characteristics of territory and religion to them. To Rohingya Muslims, they are descendants of "Muslim Arab traders" who had lived in the Rakhine State since the $9^{\text {th }}$ century during the reign of the Arakan Kingdom. As for the Buddhist ethnic groups, they believe that Islam is a religion in opposition of their beliefs or religion. In fact, the anti-Muslim sentiments are so strong in the entire country that upon question, the Myanmar population claims that the victims are the Buddhists, and not the Rohingya Muslims in Rakhine State (Schissler, Walton and Phyu Thi, 2015).

This attitude of the Buddhist Government and community has further aggravated the conflict into genocide. Venning (2015) argues that Rohingya Muslims are not on the verge of genocide, but have crossed the four out of the six stages of genocide provided by Daniel 
Feierstein in his book "Genocide as Social Practice". The first four are stigmatization; harassment, violence and terror; isolation and segregation; and systemic awakening. The last two, extermination or annihilation, and being wiped out of Myanmar's history are not far behind (Green, MacManus and Venning, 2015).

\section{THEORETICAL FRAMEWORK}

Violence is seen as a common feature of societies notably where ethnic communities are competing with each other for resources, rights, recognition or security. Several theorists have contributed towards the understanding of violence and conflict as a constant feature in these societies. Among these theories include those of Paul Collier and Anke Hoeffler - Greed and Grievances Theory, Edward Azar's Theory of Protracted Social Conflict, and Johan Galtung's Theory of Structural Violence. The distinct models developed by the theorists give further understanding of violence within a State and Society.

The Collier - Hoeffler model asserts that a rebellion may begin due to greed and not necessarily grievances of the people over a resource such as oil. The movement is then fueled by the presence of that particular resource in a geographic region. They cite economic reasons over ethnic fractionalization as a cause of conflict in the society (Collier and Hoeffler, 2002). Edward Azar, on the other hand, asserts in his Theory of Protracted Social Conflict that structural, political and societal inequalities contribute towards a conflict. The theory explains the role of various variables such as culture, society and political dynamics as being involved in a conflict (Ramsbotham, 2005). The structure of inequalities and protracted social conflict are intensified within the political and economic context (Azar and Farah, 2008). The Theory of Structural Violence professed by Johan Galtung then explains the role of violence - be it direct, cultural or structural, that leads to a conflict in a society where one group is marginalized by the other. It is Galtung's Theory of Structural Violence that this paper uses to analyze the Rohingya conflict in Myanmar.

\section{Galtung's Theory of Structural Violence}

There are many dimensions to understand the dynamics of conflict and what it entails. One of the most simplified and seminal is Johan Galtung's model that studies the relationship between conflict, violence and peace. Galtung's model not only provides a vivid framework of conflict and violence, it also coins the term "Structural Violence".

According to Galtung, there are three distinct types of violence - direct, cultural and structural, as shown in Figure 1B below. The Theory of Structural Violence predicts that people are abused and prevented from gaining their basic rights because of societal structures and institutions. Direct Violence is where the actor(s) and object(s) are readily identifiable, and Cultural Violence is when Structural Violence gets legitimized through the means of cultural ties (Ho, 2007).

The conflict model comprises of three distinct features - attitude, behavior and contradictions - as shown in Figure 1A. The attitude represents the perception and misperception of parties towards each other which leads to the second feature, i.e. behavior, which comprises of 
actions and reactions such as cooperation or coercion - a gesture that signifies either conciliation or hostility. These gestures comprise of contradictions which are often the actual or perceived incompatible goals between conflicted parties. Since conflict and violence precedes each other in a constant circle, the characteristics of conflict essentially lead to violence, whereas the relation between the conflicted parties determines the typology of violence. For instance, in direct confrontations, the actors are readily identifiable, and confrontations that drive their legitimacy from social values like culture and ethnicity evolve into cultural violence. Lastly, confrontations between social structures of States and one particular group on the basis of their respective identity lead to structural violence.

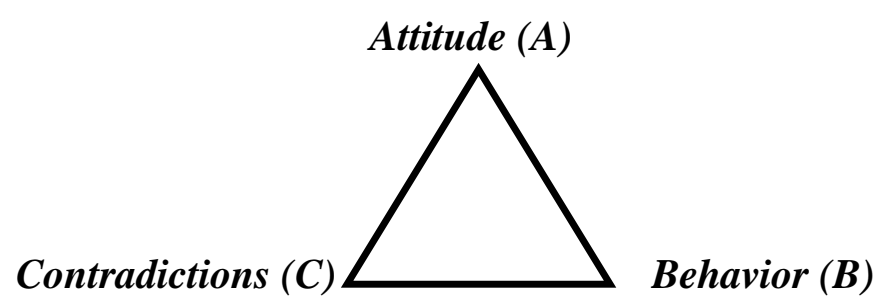

Figure 1A

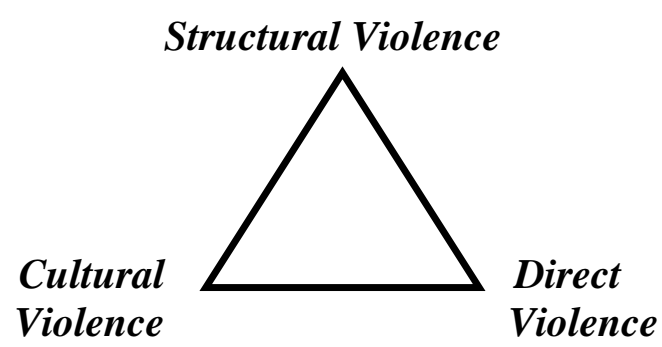

Figure 1B

Figure 1A \& 1B. Galtung's models of conflict violence. Adapted from "Contemporary Conflict Resolution", by Ramsbotham, O., Woodhouse, T. \& Miall, H. (2016), $4^{\text {th }}$ Edition, John Wiley \& Sons, pg. 9-18.

\section{Structural Violence against Rohingya Muslims}

The violence against Rohingya Muslims in Myanmar has taken many forms over time. The major reason behind this century old conflict lies in the differences of religious beliefs and the trust deficit thereof, and in this mistrust of Islamic and Buddhist community, the state suffers from turmoil. Due to the diversity of issues, this conflict has various social and cultural dimensions as well. Keeping in view the factors and evidences of the conditions of Rohingya Muslims, Structural Violence is seen as a rampant feature in the State of Myanmar. As structural barriers continue to be imposed on Rohingya Muslims, their grievances increase.

While through the lens of theory, as Galtung has explained, Structural Violence precedes as well as ensues from Direct and Cultural Violence. In manner of order, Direct Violence always involves hands on confrontation and based on instincts that drive the consciousness of human being when he/she feels anger and hatred and need for revenge. On the other hand, Cultural Violence is religious and nationalistic based, allowing human beings to force others into their bindings behind the curtains of religious protection. The Rohingya crisis is based on antipathy and extremist views of religious elites - the Buddhists vs. Muslims analogy. This hatred has turned into series of outbursts of violence from each group. The violence against Rohingya Muslims which is primarily based on cultural discrimination carried out by the institutions of the state has resulted in massive violation of human rights of the Rohingya minority.

The individual violence faced by Rohingya Muslims, for instance rape, cutting of heads, parading the Rohingya women naked around the village, or collective killings of men in circles, 
is what Galtung perceives as Direct Violence. According to the interviews conducted with Rohingya refugees who arrived in Bangladesh Refugee Camps, Rohingya women and young girls suffered rapes and sexual assaults in the hands of Myanmar Army, Myanmar Police and Rakhine villagers. Some of the women victims died as a result of gang rapes (Human Rights Watch, 2017). The burning of Rohingya villages, the looting of mosques and Islamic schools in and out of Rohingya villages, the banning of Muslim schools all over Myanmar are practical examples of Cultural Violence (Amnesty International, 2017). Additionally, social and constitutional restrictions imposed by the Government/State on the Rohingya community are forms of Structural Violence (Cheesman, 2017).

To further understand the characteristics of the typologies of violence given by Galtung, Table 1 has been drawn to explain the relationship between the typologies of violence and the situation of Rohingya Muslims in Myanmar.

Table 1: Different types of Violence and their Characteristics

\begin{tabular}{|c|c|c|c|c|}
\hline $\begin{array}{l}\text { Type of } \\
\text { Violence }\end{array}$ & Characteristics & $\begin{array}{c}\text { Visibility of } \\
\text { Abused and } \\
\text { Abuser } \\
\end{array}$ & $\begin{array}{c}\text { Tools for } \\
\text { committing } \\
\text { Violence }\end{array}$ & $\begin{array}{c}\text { Examples from Rohingya } \\
\text { Conflict }\end{array}$ \\
\hline $\begin{array}{l}\text { Direct } \\
\text { Violence }\end{array}$ & $\begin{array}{l}\text { Classic violence of } \\
\text { killing, torture, sexual } \\
\text { assault, rape, beatings, } \\
\text { verbal attacks and at } \\
\text { times war. } \\
\text { The most common form } \\
\text { of violence and most } \\
\text { unavoidable in human } \\
\text { society. }\end{array}$ & $\begin{array}{l}\text { The abuser as } \\
\text { well as the } \\
\text { abused are } \\
\text { visible for all to } \\
\text { see and point. }\end{array}$ & $\begin{array}{l}\text { Both physical and } \\
\text { mental weapons } \\
\text { based on nature of } \\
\text { conflict, i.e. } \\
\text { contention on } \\
\text { religion, self- } \\
\text { interest, ethnicity, } \\
\text { territory, etc. }\end{array}$ & $\begin{array}{l}\text { The } 969 \text { movement of } \\
\text { Buddhists against Muslims, } \\
\text { the movement was } \\
\text { responsible for hundreds of } \\
\text { deaths, rapes, and torture of } \\
\text { Rohingya Muslims, } \\
\text { especially in 2012. }\end{array}$ \\
\hline $\begin{array}{l}\text { Cultural } \\
\text { Violence }\end{array}$ & $\begin{array}{l}\text { Name to predominant } \\
\text { attitudes and beliefs that } \\
\text { help in justifying the } \\
\text { violence committed by } \\
\text { states (Structural } \\
\text { Violence). It emerges } \\
\text { when one's beliefs } \\
\text { become more important } \\
\text { and other's beliefs } \\
\text { become insignificant and } \\
\text { baseless. }\end{array}$ & $\begin{array}{l}\text { The abused are } \\
\text { more often } \\
\text { obvious but the } \\
\text { abuser hides } \\
\text { behind religion } \\
\text { and ethnicities. }\end{array}$ & $\begin{array}{l}\text { The weapons } \\
\text { used are } \\
\text { restrictions } \\
\text { imposed, } \\
\text { destruction of } \\
\text { holy places and } \\
\text { schools, etc. }\end{array}$ & $\begin{array}{l}\text { Destruction of Muslim } \\
\text { communities in Rakhine } \\
\text { State, Ban on Azaan and all } \\
\text { Muslim traditions and } \\
\text { festivals. }\end{array}$ \\
\hline $\begin{array}{l}\text { Structural } \\
\text { Violence }\end{array}$ & $\begin{array}{l}\text { Deliberate violation of } \\
\text { fundamental rights of } \\
\text { human beings especially } \\
\text { by State-backed } \\
\text { institutions. } \\
\text { Injustice and exploitation }\end{array}$ & $\begin{array}{l}\text { The abused are } \\
\text { glaringly } \\
\text { obvious but } \\
\text { abuser hides } \\
\text { behind social } \\
\text { institutions. }\end{array}$ & $\begin{array}{l}\text { Restrictions and } \\
\text { limitations } \\
\text { imposed on target } \\
\text { to group to isolate } \\
\text { them from the rest } \\
\text { of the country's }\end{array}$ & $\begin{array}{l}\text { Citizenship Act law 1989, } \\
\text { stripping Rohingya Muslims } \\
\text { of their citizenship and } \\
\text { fundamental rights. } \\
\text { State-backed attacks on } \\
\text { Rohingya Villages. Fleeing }\end{array}$ \\
\hline
\end{tabular}




\begin{tabular}{|l|l|l|l|}
\hline $\begin{array}{l}\text { through social systems } \\
\text { that create wealth for few } \\
\text { and poverty for many. }\end{array}$ & & $\begin{array}{l}\text { citizens. } \\
\text { Systematic } \\
\text { eradication from } \\
\text { past, present and } \\
\text { future of the } \\
\text { State. }\end{array}$ & $\begin{array}{l}\text { of almost entire population } \\
\text { of Rohingya to neighboring } \\
\text { countries to avoid violence } \\
\text { carried out by State, army } \\
\text { and extremist Buddhists. }\end{array}$ \\
\hline
\end{tabular}

\section{IMPACT OF STRUCTURAL VIOLENCE ON THE ROHINGYA PEOPLE}

Rakhine State has been one of the least developed parts of Myanmar, ranked second worst position in terms of overall poverty in the country (Integrated Household Living Conditions Survey, 2010); all of its inhabitants have poor access to basic services and employment opportunities. The Rohingya Muslims - majority habitants of Rakhine State, are subjected to even worse conditions. Not only are they restricted by their lack of citizenship, thereby making them ineligible to claim any rights against the Myanmar government, they are also compelled to comply with excessive obligations that constrain their lives. The strict regulations on all aspects of life of Rohingya Muslims - from traveling, to employment, to marriage and family life, serve as a constant reminder to all members of Myanmar society that Rohingya Muslims are outsiders, and that there is no place for them in Myanmar society (Mohajan, 2018). This attitude has become part of the social structure and infused itself into Myanmar's societal culture. This has been one of the reasons for cultural conflict between Rohingya Muslims and Buddhists to develop. Cultural Violence provides legitimacy to violence itself. The notion of targeting another person or community on the basis of one's religion and culture is often seen as the goodwill towards one's own religion, and most of the times, the culture of the opposition is neglected. People often tend to believe in their beliefs so staunchly that it results in extremism of all kinds of phenomenon (Lowenstein, 2015).

Abhorrence and animosity towards Rohingya Muslims have a long history that precedes Myanmar's independence. This deep-seated hatred towards this ethnic and religious group is an example of Cultural Violence which has been propagated within the Myanmar society by extremist monks and Buddhist nationalists. Among these "Buddhist nationalists" is "Ashin Wirathu", a Buddhist monk, who calls himself "Bin-Laden" of Southeast Asia (Walton, 2013). He is known for encouraging violence against Rohingya Muslims. Given his strong political and religious background, there are no protests to what he calls "purifying Myanmar from evil" by killing and oppressing Rohingya Muslims (Downs, 2013). Apart from this, Wirathu also established the "969" movement which, as per the spokesperson of the movement, was an initiative against the "Bengalis" who had illegally trespassed into Myanmar. However, the 969 movement has time and again been labeled as an anti-Muslim movement - an initiative started from fear of Islam and its expansion (Marshall, 2013). Wirathu and his movement are not only responsible for anti-Muslim violence emerging in the state, they have also played chief role in the persecution of Rohingya Muslims from Myanmar (Ghosh, 2013). 


\section{Consequences of Structural Predicaments}

The situation of the Rohingya conflict has been the same - although it started on cultural basis, soon the violence developed into direct confrontation of the opposing parties. According to Galtung's theory, Structural Violence is when state-led institutions discriminate a single community among others on the basis of prejudice - the condition of Rohingya Muslims in Rakhine State, Myanmar perhaps is the most fitting case to the theory. The north of Rakhine has several local orders and laws that allow the targeting of Rohingya Muslims; discriminatory against Rohingya people's movement and their population growth. For instance, according to one order, Rohingya couples must follow costly and time-consuming procedures to get married, and the marriage certificate itself carries multiple restrictions on family life, the number of children, and even usage of contraception. Any couple caught violating any of the "rules" must serve 10 years imprisonment (Palatino, 2016). Several examples of such localized discriminatory laws exist.

Since 2012, violent incidents of religious and extremist nationalism had spread hatred for Rohingya Muslims around the country. Today, Rohingya Muslims face violent situations in the hands of majority Myanmar community leading to the "Rohingya Muslims Conflict" to be the 21st century's largest ethnic cleansing till present (Amnesty International, 2017). In the past few years, the violence that was mostly of sexual assaults and local disputes, has quickly escalated into widespread communal clashes. All this violence has escalated and has forced Rohingya Muslims to flee Myanmar. The Muslims have resorted to using illegal methods to migrate to neighboring countries like Bangladesh and other regional states. Even there, the conditions of Rohingya Muslims are also not desirable, but still, many people seek refuge. The Bangladesh Government has not been able to accommodate so many people in the refugee camps that are under resourced. An agreement was signed between the Bangladesh Government and Myanmar Government in which it was decided that each year 300 Rohingya Muslims living in the refugee camps in Bangladesh will be sent back to Myanmar. However, Rohingya Muslims are not ready to go back and face the violence that is being carried out against them by the military of Myanmar (Al-Jazeera, 2017). This agreement has not proven itself to be useful.

\section{Deprivation of Citizenship}

Rohingya Muslims' lack of citizenship does not only deprive them of their right to nationality, but also of many other fundamental rights which entail, including lack of freedom of movement, social rights and most imperatively, the right to life. The right to nationality is considered a basic human right according to the Universal Declaration of Human Rights (UDHR). Yet, the protocol that declares this right is full of major loopholes and is often violated. Myanmar's Citizenship Law of 1982 violates the non-discrimination factor of such right as it provides three kinds of citizenship based on ulterior objectives rather than nationality criteria -

- Full citizenship

- Associate citizenship

- Naturalized citizenship 
The granting of "Full citizenship" is served for nationals who settled in Myanmar before 1823, albeit a large number of Rohingya Muslims whose ancestors had lived in Myanmar since the $8^{\text {th }}$ century onwards are the only ones not mentioned in the list of 135 recognized minorities. "Associate citizenship" is provided for those whose applications were pending before the law was enacted (Lewa, 2009). Similarly, "Naturalized citizens" are those who entered Myanmar before 1948 and have evidence for it. Other than the fact that Associate and Naturalized citizenships are considered half citizenships, they also have fewer rights than those of "Full citizenship". For instance, the right of citizenship can be revoked any time in case of the former two categories (Kugelman, 2007). Since all records regarding Rohingya Muslims were destroyed during General Ne Win's regime and crucial documents were lost, seemingly they had never "applied" for citizenship.

\section{Restrictions to freedom of movement}

Rohingya Muslims have been facing restrictions and limitations on their right of movement for decades. But as the conflict escalated in 2012, limitations further tightened to a limit that even moving to the next village and staying overnight required official permit which itself would take days before it was granted. Although the Government justified the strict limitations as a solution to contain the incidences of violence, the policies were targeted against Rohingya Muslims alone. It was mandatory for Rohingya Muslims to comply with the authorities, otherwise, the situation would lead to extortions and harassment by law enforcers and public officials (Chalermpalanupap, 2016).

\section{Rohingya refugee crisis for neighboring states}

Even though human rights violation of Rohingya Muslims in Myanmar remains the core crisis of the conflict, the important perspective to the Rohingya conflict has been taken up by the Rohingya refugee crisis because a large section of the population of Rohingya Muslims that resided in Myanmar is now displaced and living as refugees in neighboring countries. This wave of refugee crisis in the region is important because apart from being a major concern in itself and affecting the whole region, it has also led to other crimes, such as trafficking and smuggling network, to emerge as well. These crimes are not only facilitating the migration flows, but are also reasons for the abduction and killings of hundreds of Rohingya Muslims.

\section{Threats to life, liberty and security}

Rohingya Muslims constantly deal with harassment, looting of their homes, humiliation, rape, forced labor, arbitrary arrests, or just simply, killings. The conditions Rohingya Muslims have to live with in Myanmar are dire and absolutely violate their right to life, security and freedom. Rohingya Muslims have been living in complete lockdown in Myanmar with living standards below that of poverty limit (UNHCR, 2014). Myanmar's policies have rendered Rohingya Muslims vulnerable as their statelessness makes them the most victimized minority. The attempts to exclude Rohingya Muslims by the Government are as follow (Jacques, 2005) -

- To expel Muslims from their jobs

- To shutdown Islamic Schools, Institutes and other organizations with Islamic affiliation

- To seize Muslim properties and distribute them within the Buddhist population 
- To imprison or exile freedom fighters and leaders who speak for Rohingya Muslims

The antagonism against 'Rohingyan' has turned citizens of Myanmar against Rohingya Muslims (Marston, 2016; Human Rights Watch, 2013).

\section{Physical and Psychological Violence}

Stories of Rohingya women getting raped either during raids or when they were trying to flee have been a common report for Rohingya Muslims. High rates of exposure to sexual and gender based violence in Myanmar and countries where Rohingya Muslims are seeking asylum has been reported by a range of humanitarian agencies and human rights organizations (UNHCR, 2018). Nevertheless, it is difficult to provide accurate documentation of these crimes and abuses because of the stigma and fear of retaliation if these are reported by female survivors. Survivors of these abuses have to face societal pressure and psychological abuse. Refugee women arriving in Bangladesh in 2017 gave testimonies that they were forced into prostitution and faced sexual molestation and gang rapes by Myanmar military and other ethnic groups of Rakhine State (Human Rights Watch, 2017; Sultana, 2018).

\section{Denial of the right to education}

The deprivation of their right to education also denies them the opportunity of interaction and reconciliation with other communities. This includes their lack of knowledge regarding their situation. One of the major challenges they face is assessing education in general, particularly university education. Since many of Rohingya Muslims do not know how to read and write, there is almost nil chance of them fighting for their own rights. The lack of knowledge makes Rohingya Muslims victims of societal discrimination and vulnerable to violence committed by Myanmar military and other ethnic groups.

\section{Limitation on political rights and documentation}

The "Temporary identity certificates" that were held by around 700,000 stateless people in Myanmar including Rohingya and other minorities were stripped away when the Government announced the expiration of the policy in February 2015. For many minority groups, those certificates were the primary documents that justified their legal residence in Myanmar - thus, Rohingya Muslims were once again stateless. The expiration of the policy which was imposed before the 2015 elections was a deliberate move to ensure Rohingya Muslims could not participate in the elections and fight for their rights.

\section{Falling Victims to Human Trafficking and Smuggling}

The Government of Myanmar has made Myanmar Army autonomous from the Civilian Government and this has allowed the military to flagrantly disregard the International Legal Obligations Myanmar has as part of international community. Myanmar is one of the only few states which did not ratify majority of International Conventions or protocols despite being mentioned multiple times in United Nations Reports (Global Justice Centre, 2012). Similarly, despite acknowledging the 2000 Protocol to Prevent, Suppress and Punish Trafficking in 
Persons, and the 2000 United Nations Convention against Transnational Organized Crime (UNODC, 2003), Myanmar has yet to ratify them. Rather, they expressed reservations against its Article 15, and consider themselves not bound to obligations to refer disputes relating to the Protocol to the International Court of Justice (ICJ) (UN Treaty Collection, 2000).

Myanmar's disregard of international customs and basic human rights have caused half of the Rohingya Muslims population to fall victims of human trafficking and human smuggling from within Myanmar. During their quest to gain asylum, many Rohingya Muslims were killed by smugglers, buried or drowned (Human Rights Watch, 2013; US Department of States 20092017). The plight of Rohingya Muslims has been to flee Rakhine State, however, with no identification documents, and being in complete lockdown by the Government of Myanmar, some of the victims have no other options available, but to bribe smugglers to take them to neighbouring states. The Rohingya crisis emerged on international media in 2015 when these smuggled Rohingya Muslims were stranded at the ports of Malaysia and Thailand (BBC News, 2015). Following this crisis, mass graves were discovered in Southern Thailand where Rohingya Muslims who were fleeing to Malaysia were buried (UNHCR, 2018).

Table 2: Consequences of Structural Predicaments and their features

\begin{tabular}{|c|c|c|c|}
\hline Features & Direct Violence & Cultural Violence & Structural Violence \\
\hline $\begin{array}{c}\text { Deprivation of } \\
\text { Citizenship }\end{array}$ & $\checkmark$ & - & $\checkmark$ \\
\hline $\begin{array}{c}\text { Restrictions on } \\
\text { Movement }\end{array}$ & - & - & $\checkmark$ \\
\hline Refugee Crisis & $\checkmark$ & - & $\checkmark$ \\
\hline $\begin{array}{c}\text { Threat to life, liberty } \\
\text { and security }\end{array}$ & $\checkmark$ & $\checkmark$ & $\checkmark$ \\
\hline $\begin{array}{c}\text { Sexual and Gender } \\
\text { Based Violence }\end{array}$ & $\checkmark$ & $\checkmark$ & $\checkmark$ \\
\hline $\begin{array}{c}\text { Denial of Education } \\
\text { Limitation on } \\
\text { political rights }\end{array}$ & $\checkmark$ & $\checkmark$ & $\checkmark$ \\
\hline Forced Labor & $\checkmark$ & $\checkmark$ & $\checkmark$ \\
\hline Trafficking & $\checkmark$ & - & $\checkmark$ \\
\hline
\end{tabular}

\section{REGIONAL RESPONSE TO THE ROHINGYA CONFLICT}

ASEAN, the regional body of South East Asia, was formed on the basis of "sharing and caring", and its purpose of formation was humanity. However, ASEAN has yet to make any positive and 
productive decision in the case of Rohingya Muslims. The lack of ASEAN's response is due to its non-intervention policy, allowing Myanmar to deal with its "domestic" conflict in the way it wants (Baskoro, 2016). However, it is also in the ASEAN Charter that every member state must respect fundamental human rights and provide them to their people. The definition of intervention/interference opted for this paper is broad in its meaning: an activity undertaken by the state, a Group within a state or an International Organization which interferes in the domestic (local) affairs of another state" (Jones, 2014). Non-Interference is also a policy indorsed within Article 2(4) of the UN Charter which states that all members should refrain from using threat of or use of force against the territorial integrity or political independence of another state in their international relations.

ASEAN was a result of an effort to avoid war, hence according to Article 1 of the ASEAN Charter, ASEAN would be responsible to keep peace, security and stability of the region, and similarly further down, Article 7 claims that ASEAN and by stretch, the signatories of ASEAN, would abide by international law and respect human rights (ASEAN Charter 2008, 2015). In order to further promote its rule and legitimacy of its Charter, ASEAN has affiliated itself with the regional as well as extra regional major powers, which helps ASEAN in its working as a regional human rights protectionist body.

Yet, today ASEAN fails to address the Rohingya problem because of Article 2(2)(e) of its Charter under which ASEAN asserts that its member states would not interfere in the domestic matters of all and any member state of ASEAN. Incidentally, two decades ago when Suu Kyi was fighting for democracy against Myanmar's military dictatorship, ASEAN's nonintervention policy was heavily criticized by her. In a newspaper editorial published in 1999, Suu Kyi made a statement regarding the "irritating policy", that "policy of non-intervention is just an excuse for not helping". Clearly Suu Kyi was against the policy of ASEAN when she was fighting for the "right thing". However, now with the Rohingya conflict where thousands have been killed and millions have been displaced, Suu Kyi finds intervention of ASEAN, or even the UN or UNHCR, "disrespectful" (Htusan, 2017). Suu Kyi has even banned foreign aid for Rohingya Muslims through a countrywide blockade. The UN has been pressuring the Myanmar Government to take measures to stop the violence against Rohingya Muslims, but all the claims regarding any kind of violence have been refuted, and army operations in villages inhabited by Rohingya Muslims have been declared as self-preservation against Rohingya terrorism (Taiwan \& Yoon, 2017).

As a leader who had won the Nobel peace prize in 1991 for her non-violent fight for democracy in Myanmar, Suu Kyi has certainly failed at protesting against the atrocities committed by Myanmar's military and Buddhist majority against Rohingya Muslims in the very same Myanmar. According to David Mathieson, a former Human Rights researcher, "ASEAN summits are not designed to respond to any major human rights conflicts that would be concern for the entire region" and to him, Suu Kyi is greatly benefitting from ASEAN's inability to respond to crisis (Htusan, 2017). The ASEAN Summit in November 2017 was a hope for others that finally in the presence of the USA and China, ASEAN and the major powers would leave the summit with significant actions taken against Myanmar, however, no significant action was taken. (Human Rights Watch, 2017). 


\section{Malaysia's Regional Role}

As Rohingya's strongest advocate in the region, Malaysia has been giving statements and has severed ties with Myanmar (blocking visas to Myanmar) in an apparent show of protest against violation of rights of Rohingya Muslims. Earlier in 2017, Malaysia had distanced itself from a statement issued by the Philippines, the current chairman of ASEAN, after the attacks of 25th August in Rakhine State (Pusspitaningtas, 2017). Malaysia, right after the release of the collective statement from ASEAN by the Philippines, stated that Malaysia had already expressed its views to the Chairman, and the statement was not based on mutual consensus because the Philippines not only had downplayed the crisis, but also "forgot" to mention Rohingya Muslims in the said statement, further cementing the expression of ASEAN on the Rohingya Crisis, of which Malaysia was very much against (Callar, 2017). Similarly, Indonesia has been using shuttle diplomacy with Suu Kyi to find productive solutions for the Rohingya crisis (Fuller \& Lyons, 2015). Regarding the rift within ASEAN, Indonesia, like a true diplomat, through a statement made by Marty Natalegawa - the former Foreign Minister of Indonesia, claims that ASEAN has enough calibre to overcome this temporary rift (Zein, 2017).

Other than Malaysia, Thailand, and Indonesia, no other state in South East Asia is directly involved in the conflict, but each has been condemning Myanmar for its actions because the conflict is taken to have affected all Muslims equally. After the attacks of 25th August 2017, when Muslims in the region started protesting, Singapore called for a ceasefire from all the governments of ASEAN, claiming that those protests would only aggravate the conflict rather than resolving it. Singapore's Ministry of Foreign Affairs (MFA) had released a statement claiming that it was willing and prepared to deal with the Myanmar Government to restore peace and stability in the country for it is a national, as well as a regional goal (Leong \& Soeriaatmadja, 2017). Apart from this, the Singapore's MFA also offered its "deepest condolences" to the victims and their families in Rakhine State and promised to stand by and support efforts by ASEAN to utilize the mechanisms to provide humanitarian assistance to them. ASEAN needs a firmer policy in response to the Myanmar-Rohingya crisis. Members need to stand united and follow practical steps like Malaysia and sever ties with Myanmar and impose definitive sanctions to pressure the Government of the State of Myanmar.

\section{CONCLUSION}

The Rohingya conflict has roots in history, culture and religion. Several facts of this situation have resulted in a crisis situation where a community of people residing within a state has been rendered stateless by their own country. The origin of the Rohingya Muslims in the state of Myanmar is contested between the ethnic community and the State. The conflict has turned violent as the State of Myanmar continues to deny these people their rights of citizenship, and the non-recognition of them being a minority in the State of Myanmar. Keeping this in view, several structural barriers that exist against the Rohingya people have left them deprived of basic rights to citizenship, education, security and culture, among others. Johan Galtung had discussed three forms of violence in his typology of violence - Direct, Cultural and Structural. In the case of Rohingya Muslims in Myanmar, all three are prevalent, whereby Structural Violence in particular, stands out. The effects of these forms of violence on this ethnic community have 
scarred them forever. They now seek refuge in neighboring states in the most questionable circumstances due to the lack of resources in the state and aid agencies.

The Rohingya conflict caught global attention when thousands of Rohingya Muslims were found at the borders of neighboring states fighting for their survival when an ethnic conflict situation turned into one of ethnic cleansing. As this becomes a regional concern, ASEAN should be, and to a certain limited extent has been, able to play a strong role. The issue of Myanmar and Rohingya Muslims is important as its distinct features and geographical location affect a number of neighboring states. Neighboring states have been playing their role in highlighting the issues and pressuring the State of Myanmar to deal with the situation, but unless the Structural Violence of the State is addressed, the Rohingya crisis may continue to erode and affect the entire region.

\section{REFERENCES}

Ahmed, A. "The Rohingya: Myanmar's outcasts" (2012, January 30), Al Jazeera English. Retrieved https://www.aljazeera.com/indepth/opinion/2012/01/201212710543198527.html

Al-Jazeera. "Myanmar, Bangladesh sign Rohingya return deal" (2017, November 23), AlJazeera News. Retrieved from: https:/www.aljazeera.com/news/2017/11/myanmarbangladesh-sign-rohingya-return-deal-171123103014940.html.

ASEAN. "The official of ASEAN charter" (2018, September 10), ASEAN. Retrieved from: https://www.asean.org/wp-content/uploads/2012/05/11.-October-2015-The-ASEAN-

Charter-18th-Reprint-Amended-updated-on-05_-April-2016-IJP.pdf.

Azar, E. E. \& Farah, N. (1981), The structure of inequalities and protracted social conflict: A theoretical framework. Journal of International Interactions; Empirical and Theoretical Research in International Relations, 7, 4, DOI: 10.1080/03050628108434558.

Bahar, A. S. "Burma's missing dots in chronology: A timeline of Burma's Rohingya history in Arakan" (2018, July 26), Network for International Protection of Refugees and Burma Action Group (South Australia). Retrieved http://www.netipr.org/policy/downloads/20100101_timeline-of-rohingya-history.pdf

Bahar, A. S. (2010). Burma's missing dots: The emerging face of genocide. Montreal: Xlibris.

Bazar, C. "NGO ban hurting undocumented Rohingya" (2012, December 17), The New Humanitarian News. Retrieved From https://www.thenewhumanitarian.org/fr/node/252945

BBC News. "Why are so many Rohingya Migrants stranded at sea?" (2015, May 18), BBC News. Retrieved from https://www.bbc.com/news/world-asia-32740637

Callar, M. "Malaysia opposes Cayetano's ASEAN Chair statement on Rohingya Crisis” (2017, September 25), GMA News Network. Retrieved from: http://www.gmanetwork.com/news/news/nation/627029/malaysia-opposes-cayetano-sasean-chair-statement-on-rohingya-crisis/story/. Accessed on: 11 $1^{\text {th }}$ December 2017. 
Chalermpalanupap, T. "Myanmar's Rohingya crisis is ASEAN's responsibility" (2016, December 8), The Diplomat. Retrieved from: https://thediplomat.com/2016/12/myanmarsrohingya-crisis-is-aseans-responsibility/.

Cheesman, N. (2017) Introduction: Interpreting communal violence in Myanmar. Journal of Contemporary Asia, 47, 3, 335-352.

Chia, J. "The truth about Myanmar's Rohingya conflict: It is much more complex than is often portrayed by some" (2016, March 5), The Diplomat. Retrieved from: http://thediplomat.com/2016/03/the-truth-about-myanmars-rohingya-conflict/.

Chowdhury, M. A. "The advent of Islam in Arakan and Rohingyas" (2006, October 22), Kaladan Press Network. Retrieved From https://www.kaladanpress.org/index.php/scholarcolumn-mainmenu-36/36-rohingya/217-the-advent-of-islam-in-arakan-and-therohingyas.html

Collier, P. \& Hoeffer, A. (2004) Greed and grievance in civil war. Oxford Economic Papers, 56, 4, 563-595.

Crouch, M. (Ed.). (2016). Islam and the state in Myanmar: Muslims-Buddhist relations and politics of belonging. Oxford: Oxford University Press.

Dittmer, L. (2010). Burma vs. Myanmar: What's in the name? In L. Dittmer (Ed.). Burma or Myanmar? The struggle for national identity (pp. 1-20). River Edge: World Scientific Publishing Co.

Downs, R. “Is Burma's anti-Muslim violence led by Buddhist Neo-Nazis?” (2013, March 28), VICE News. Retrieved From https://www.vice.com/da/article/mvpy3n/is-burmas-antimuslim-violence-led-by-buddhist-neo-nazis

Fuller, T. \& Lyons, P. J. "How Myanmar and its neighbors are responding to the Rohingya crisis. (2015, May 13), The New York Times. Retrieved from: https://www.nytimes.com/interactive/2015/05/13/world/asia/15rohingya-explainer.html.

Ghosh, N. "Anti-Muslim monk changes tack, vows to promote peace” (2013, April 1), The Straits Times. Retrieved From https://eresources.nlb.gov.sg/newspapers/digitised/issue/straitstimes20130401-1\#

Global Justice Centre. "Myanmar/Burma's binding obligations under international law” (2012, November 30), Global Justice Centre. Retrieved from: http://globaljusticecenter.net/documents/BindingObligations.pdf.

Ho, K. (2007), Structural violence as a human rights violation. Essex Human Rights Review, 4, 2, $1-17$.

Htusan, E. “Aung San Suu Kyi is benefiting from ASEAN's silence on Myanmar's Rohingya crisis" (2017, November 13), The Times. Retrieved from: http://time.com/5021138/myanmar-rohingya-asean-aung-san-suu-kyi/

Human Rights Watch. "All of my body was pain: Sexual violence against Rohingya women and girls in Burma” (2017, November 16), Human Rights Watch. Retrieved From 
https://reliefweb.int/report/myanmar/all-my-body-was-pain-sexual-violence-againstrohingya-women-and-girls-burma

Human Rights Watch. "All you can do is pray: Crimes against humanity and ethnic cleansing of Rohingya Muslims in Burma's Arakan state" (2013, April 22), Human Rights Watch. Retrieved from: https://www.hrw.org/report/2013/04/22/all-you-can-do-pray/crimes-againsthumanity-and-ethnic-cleansing-rohingya-muslims

Jacques, P. L. "Arakan studies: Challenges and contested issues, mapping a field of historical and cultural research" (2007, June 22), Kalaban Press Network. Retrieved From https://www.kaladanpress.org/index.php/seminar-and-event-mainmenu-38/58-arakanhistorical-seminar/699-arakanese-studies-challenges-and-contested-issues-mapping-a-fieldof-historical-and-cultural-resear.html

Jones, L. (2014), Explaining Myanmar's regime transition: The periphery is central. Journal of Democratization, 21, 5, 780-802.

Kugelman, D. (2007), The protection of minorities and indigenous peoples respecting cultural diversity. Max Planck Yearbook of United Nations, 11, 233-263.

Leider, P.J. "Rohingya: The name, the movement, the quest for identity” (2014, 28 January), Network Myanmar. Retrieved From http://www.networkmyanmar.org/ESW/Files/LeiderRohingya.pdf

Lewa, C. (2009), Northern Arakan: An open prison for the Rohingya in Burma. Forced Migration Review, 32, 11-13.

Lowenstein, K. A. (2015), "Persecution of the Rohingya Muslims: Is genocide occurring in Myanmar's Rakhine state?" (2015, October), International Human Rights Clinic, Yale Law School. Retrieved From https://www.fortifyrights.org/downloads/Yale_Persecution_of_the_Rohingya_October_2015 .pdf

Macmanus, T., Green, P. \& de la Cour Venning, A. "Countdown to annihilation: Genocide in Myanmar” (2015, October 29), International State Crime Initiative, Queen Mary University London. $\quad$ Retrieved From https://qmro.qmul.ac.uk/xmlui/bitstream/handle/123456789/25375/Green\%20COUNTDOW N\%20TO\%20ANNIHILATION\%3a\%20GENOCIDE\%20IN\%20MYANMAR\%202015\%2 OPublished.pdf?sequence $=1 \&$ isAllowed $=\mathrm{y}$

Mohajan, H. "History of Rakhine state and the origin of the Rohingya Muslims" (2018, July 28). Munich Personal RePEc Archive Paper No. 88186. Retrieved From https://mpra.ub.unimuenchen.de/88186/1/MPRA_paper_88186.pdf

MRGI. "World directory of minorities and indigenous peoples - Myanmar/Burma: Muslims and Rohingya" (2017, October), Minority Rights Group International. Retrieved From https://www.refworld.org/docid/49749cdcc.html

Palatino, M. “Myanmar's radical Buddhist group gets rebuked” (2016, July 20), The Diplomat. Retrieved from http://www.thediplomat.com/2016/07/myanmars-radical-buddhist-groupgets-rebuked/. 
Pisharoty, S. B. "The frictions in the Rakhine state are less about Islamophobia than RohingyaPhobia" (2017, September 30), The Wire. Retrieved from: https://thewire.in/externalaffairs/frictions-rakhine-state-less-islamophobia-rohingya-phobia

Pusspitaningtas, Y. "Resolving the Rohingya crisis the ASEAN way" (2017, September 7) Jakarta Post. Retrieved from: https://www.thejakartapost.com/academia/2017/09/07/resolving-the-rohingya-crisis-theasean-way.html

Ramsbotham, O. (2005), The analysis of protracted social conflict: A tribute to Edward Azar". Review of International Studies, 31, 1, 109-126.

Ramsbotham, O., Woodhouse, T. \& Miall, H. (2016) Contemporary Conflict Resolution (4th Edition). Cambridge: Polity Press).

Saw, K. M. "Islamization of Burma through Chittagonian Bengalis as Rohingya refugees" (2011, September 8), Burma Library. Retrieved From https://www.burmalibrary.org/docs21/Khin-Maung-Saw-NM-2011-09-

Islamanisation_of_Burma_through_Chittagonian_Bengalis-en.pdf

Schissler, M., Walton, M, J., \& Thi, P. P. "The roots of religious conflict in Myanmar: Understanding narratives is an important step to end violence" (2015, August 6), The Diplomat. Retrieved from: https://thediplomat.com/2015/08/the-roots-of-religious-conflictin-myanmar/

Sultana, R. "Rape by command: Sexual violence as a weapon against the Rohingya" (2018, February 21), Kalandan Press. Retrieved from: https://www.kaladanpress.org/images/document/2018/RapebyCommandWeb3.pdf

Szep, J. \& Marshall, R. C. (2013), "Special report: Thailand secretly supplies Myanmar refugees to trafficking rings" (2013, December 5). Reuters. Retrieved from: http://www.reuters.com/article/2013/12/05/us-thailand-rohingya-special-reportidUSBRE9B400320131205.

Tay, A.K., Islam, R., Riley, A., Welton-Mitchell, C., Duchesne, B., Waters, V., Varner, A., Silove, D. \& Ventevogel, P. "Culture, context and mental health of Rohingya refugees: A review for staff in mental health and psychosocial support programmes for Rohingya refugees" 92018, October 9), UNHCR Report. Retrieved From https://www.unhcr.org/5bbc6f014.pdf

Ullah, A. A. (2011) Rohingya refugees to Bangladesh: Historical exclusions and contemporary marginalization. Journal of Immigrant \& Refugee Studies, 9, 2, 139-161.

UNCHR. "Text of the 1961 convention on the reduction of statelessness" (2019, September), United Nations High Commissioner for Refugees. Retrieved From: https://www.unhcr.org/ibelong/wp-content/uploads/1961-Convention-on-the-reduction-ofStatelessness_ENG.pdf

UNHCR. "Expert meeting: The concept of stateless persons under international law: Summary conclusions" (2010, May 28), United Nations High Commissioner for Refugees. Retrieved 
From https://www.unhcr.org/en-my/protection/statelessness/4cb2fe326/expert-meetingconcept-stateless-persons-under-international-law-summary.html

United Nations. "Chapter XVIII: Penal matter” (2019, September), UN Treaties. Retrieved from: https://treaties.un.org/Pages/ViewDetails.aspx?src=TREATY\&mtdsg_no=XVIII-12a\&chapter=18\&lang=en\#EndDec.

UNODC. "Signatories to the united nations convention against transnational crime and its protocols, united nations office on drugs and crime" (2003, September 29), UNODC. Retrieved from: https://www.unodc.org/unodc/en/treaties/CTOC/signatures.html.

US. "Country reports on human rights practices for 2015" (2019, September 17), US Department of State. $\quad$ Retrieved from https://20092017.state.gov/j/drl/rls/hrrpt/humanrightsreport//index.htm\#wrapper

Walton, M. J. (2013) Buddhism Turns Violent in Myanmar. Asia Times, 2, N. A.

Wolf, S. O. "Genocide, exodus and exploitation for Jihad: The urgent need to address Rohingya crisis. (2017, September 26), South Asia Democratic Forum. Retrieved From https://www.sadf.eu/sadf-working-paper-6-genocide-exodus-exploitation-jihad-urgent-needaddress-rohingya-crisis-siegfried-o-wolf/

Yoon, M. “ASEAN II: Human Rights \& ASEAN'S Role” (2017, May 19), Yale Model United Nations - Taiwan. Trom https://social.shorthand.com/ymuntaiwan/3giVTdUWE6/asean-ii-human-rights-and-aseansrole

Zein, Z. M. "ASEAN lacks unity as need to address Rohingya Crisis grows" (2017, October 9), The Globe Post. Retrieved From https://theglobepost.com/2017/10/09/asean-rohingyarepatriation/ 